\title{
Mentorit pk-yritysten kehittämisen tukijoiksi
}

M

entorointi on noussut näyttävästi esiin yrittäjien yhtenä liiketoimintaosaamisen kehittämismuotona. Suomessa hallituksen politiikkaohjelmien yritysosuuksissa mainitaan pk-yritysten toiminnan tukijoina myös epämuodollisesti toimivat yrittäjävalmiuksien tarjoajat. Mentorit ovat juuri heitä.

Yrittäjäkasvatuksen ja -koulutuksen teoreettisessa viitekehyksessä mentorointi sisältyy yrittäjävalmiuksien parantamisen aihepiiriin. Katsantokanta on kuitenkin hyvin käytännöllinen - mentorit ovat omalla urallaan kokeneet, nähneet ja tehneet laaja-alaista yritystoimintaa. Organisoidussa mentoritoiminnassa he jakavat kokemustaan ja osaamistaan yrittäjien käytettäväksi, vapaaehtoisesti ja usein vielä korvauksetta.

\section{Mitä mentorointi on?}

Mentorointi tarkoittaa tässä yhteydessä mentorin yrittäjälle antamaa tukea. Mentori on osaava, kokenut ja arvostettu senioriasemassa toimiva henkilö. Hän on usein itsekin taustaltaan yrittäjä, liikkeenjohtaja tai asiantuntija. Tuen kohteena on kehityshaluinen ja-kykyinen, tavallisesti nuori ja toimintaansa aloittava yrittäjä. Mentorointi soveltuu mainiosti myös vakiintuneelle yritykselle, yrittäjäpolven-vaihdoksen läpivientiin ja muuhun strategiseen toiminnan muutokseen.

Mentorin ja tuettavan yrittäjän eli aktorin välinen yhteistyö on tavoitteellista, kahdenkeskistä, luottamuksellista sekä avointa vuorovaikutusta.
Suhde on siis aina kaksisuuntainen. Mentori on tiedon välittäjä ja yleensä puolueeton. Hän ei pyri vaikuttamaan yrittäjän johtamiseen ja päätöksentekoon. Yrittäjä puolestaan on mentorista riippumaton ja itsenäinen. Hän käyttää yrityksensä hyödyksi mentorilta saamiaan tietoja ja neuvoja.

HSE Pienyrityskeskus käynnisti pääkaupunkiseudulla ensimmäisen mentoreiden koulutusohjelman vuonna 2005. Eri valmennusjaksojen tuloksena alueelle syntyi 102 Auktorisoidun Business Mentorin verkosto, jota Pienyrityskeskus hallinnoi.

Pääkaupunkiseudun kokemusten perusteella Pienyrityskeskus organisoi syksyllä 2007 ja tammikuussa 2008 kaksi valmennusjaksoa Mikkelissä eteläsavolaisille mentoroinnista kiinnostuneille. Maakuntaan syntyi 62 mentorin tietokanta ja heitä valjastetaan parhaillaan yrittäjien käyttöön.

Helsingin kauppakorkeakoulun New Business Center-yrityshautomo on järjestänyt Helsingissä useita pienimuotoista hautomoyrittäjien ja mentoreiden tapaamista. Ne ovat olleet hyvin suosittuja ja uusia mentorointisuhteita on saatu aikaiseksi. Pienyrityskeskus on toteuttanut tällaisia tapaamisia myös Mikkelissä ja kokemukset ovat olleet rohkaisevia. Yrittäjillä, erityisesti vastikään toimintansa aloittaneilla, mutta myös vakiintuneilla yhtiöillä on selkeästi tarve mentorointiin. Yrittäjät etsivät mentorista vertaistaan keskustelukumppaniksi, innostajaksi ja osaltaan myös ajatustensa kriitikoiksi. 
Kuinka mentorointi saadaan

\section{liikkeelle?}

Pääkaupunkiseudun mentorit ovat pääsääntöisesti Uudenmaan 15 yrityshautomon käytettävissä. Hautomoyrityksiä on noin 300. He saavat mentoryhteyden kätevimmin suoraan hautomonsa organisaatiosta.

Etelä-Savossa mentorhanke odottaa jatkorahoitusta. Kun se kevään aikana myönnetään, Pienyrityskeskus kouluttaa alueen kaikki julkista yritysneuvontaa tarjoavat yksiköt mentorverkoston aktiivisiksi käyttäjiksi. Tällöin yrittäjä saa pulmaansa soveltuvan mentorin lähimmästä elinkeinopalveluja tarjoavasta pisteestä.

\section{Yhteistyö tuo tuloksia}

"Mentorointi tuplasi yritykseni liikevaihdon”, kenkäkauppias Silja Viljanen riemuitsee hänestä valtakunnalliseen Yrittäjä-lehteen (01/2007) tehdyn jutun otsikossa. Viljanen perusti Poriin kenkäkaupan ja sai heti alusta pitäen tuekseen kokeneen yrittäjän, oman mentorinsa. Samaisessa artikkelissa niin yrittäjä kuin mentorikin ilmaisevat tyytyväisyytensä yhteistoimintaan.

Esimerkkijuttua useammin mentori on avannut nuorelle yritykselle toimivia asiakasyhteyksiä, joista on kehittynyt merkittävää liiketoimintaa. Mentoreiden kontaktit ulottuvat lähes kaikkialle maailmaan, joten aktiivinen yrittäjä saa siitä tehokasta vetoapua markkinoille.

\section{Mitä yrittäjä höytyy mentoristaan?}

Mentoreilla on usein pitkä yrittäjäkokemus tai työura vastuunalaisissa tehtävissä vieraan palveluksessa. Heillä on siis hyvä näköala yrittäjän arkeen. Mentorit ovat lohduttaneet yrittäjää kassakriisissä ja riemuinneet hänen kanssaan onnistuneesta pörssilistautumisesta - janan kummassakin päässä yrittäjällä on tarvetta ulkopuolisen uskotun apuun.

Kansainvälisten tutkimusten mukaan yrittäjät ovat saaneet mentorista hyötyä erityisesti liiketoimintansa kriittisissä vaiheissa. Mentori on paikalla juuri silloin, kun hänen neuvojaan ja näkemystään tarvitaan. Avun antaminen ei ole riippuvaista sovituista konsulttipäivistä. Toisaalta yrittäjän arki tuo pohdittavaa ennakkoon sovituista aikatauluista riippumatta. Yrityksen mentori on käytettävissä pikaisestikin ja yrittäjä saa asiantuntevan sekä ulkopuolisen näkemyksen ongelmaansa. Tämän tutkimuksissa esiinnousseen pika-avun lisäksi yrittäjä hyötyy mentorisuhteesta myös pitkällä aikavälillä, koska mentoroinnin tavoitteena on pitkäjänteinen yhteistyö.

Mentorointi ei toki korvaa yrittäjän omaa jatkuvaa kouluttautumisen vaatimusta. Usein mentoriyhteistyö syventää ja laajentaa kurssitusten ja konsultointien antia.

\section{Seppo Rantalainen}

